\title{
C-kit receptor in the human vas deferens: distinction of mast cells, interstitial cells and interepithelial cells
}

\author{
Roman Metzger, Udo Rolle, Henning C Fiegel, Folker E Franke ${ }^{1}$, Karsten Muenstedt ${ }^{1}$ \\ and Holger Till \\ Department of Pediatric Surgery, University of Leipzig, 04103 Leipzig, Germany and ${ }^{1}$ Department of Pathology, \\ University of Giessen, 35392 Giessen, Germany \\ Correspondence should be addressed to R Metzger; Email: roman.metzger@medizin.uni-leipzig.de
}

\begin{abstract}
The molecular mechanisms underlying the regulation of vas deferens (VD) motility and semen emission are still poorly understood. Interstitial cells of Cajal (ICC), which harbour the c-kit receptor (CD117), provide the basis of coordinated gut motility. We investigated whether c-kit receptor-positive cells also exist in the normal human VD. Enzyme and fluorescence immunohistochemical techniques were applied on serial sections of human proximal, middle, and distal VD segments $(n=49)$ employing 13 different monoclonal and polyclonal antibodies recognizing the c-kit receptor. The c-kit receptor was detected in either round- or spindle-shaped cells. On account of their antigenic profile, the round- and oval-shaped c-kit receptor-positive cells were identified as mast cells (MC) occurring in all layers of the VD except the epithelium. In contrast, two distinct populations of exclusively c-kit receptor-positive spindle-shaped cells were found within the lamina propria and, rarely, in the inner and outer smooth muscle layers, as well as within the epithelium. Different shaped c-kit receptor-positive MC and IC were present in all layers of the human VD. Our findings demonstrate the presence of different c-kit receptor-positive cells also in the human VD. Their rather ubiquitous distribution within the lamina propria and muscle layers suggests that IC and MC may modulate the neuromuscular transmission and the propagation of electrical signals in multiple systems involved in the draining of fluids. The importance of the c-kit receptor-positive interepithelial cells remains unclear.

Reproduction (2008) 135 377-384
\end{abstract}

\section{Introduction}

The interstitial cells of Cajal (ICC) are known to play an important role in the control of gut motility by providing electrical impulses for slow wave smooth muscle activity and neurotransmission (Huizinga et al. 1995). The ICC cell membrane harbours the c-kit receptor (CD117), which allows the identification of these cells by immunochemical and molecular methods (Lammie et al. 1994). ICC were found primarily close to the intestinal myenteric plexus, and also in the submucosal plexus and septa of the muscle layers. Lack or absence of c-kit immunoreactivity in the gut has been associated with gastrointestinal motility disorders (Yamataka et al. 1995, Streutker et al. 2003).

Recently, we have demonstrated the unique distribution of Cajal-like cells (CLC) in the normal upper urinary tract in humans and various animal species (Metzger et al. 2004, 2005). There is an ongoing discussion whether or not these CLC provide peristaltic activity in the upper urinary tract. A recent publication showed the ability of CLC to trigger contractions of the neighbouring smooth muscles of the ureterovesical junction in the mouse (Lang et al. 2007).
Similar to the ureter, the molecular mechanisms underlying the regulation of vas deferens (VD) motility are still poorly understood. The detection of cells representing a potential pacemaker system in the VD may improve our understanding of neurophysiological and pathological conditions of the male genitourinary tract.

Therefore, the present study analyses the cellular localization and distribution of c-kit receptor-positive cells in the human VD using a panel of monoclonal and polyclonal antibodies (pAb).

\section{Results}

All anti-c-kit receptor antibodies showed a uniform reaction pattern. The staining results were comparable using paraffin or frozen sections. Furthermore, no differences were found between cancer and autopsy cases. Special reference regions were used and the resulting staining density did not reveal specific differences between the used different mono- and polyclonal c-kit antibodies.

The c-kit receptor was detected in three different cell types. The first source occurred in spindle interstitial 
cells (IC) that demonstrate an oval nucleus and a bipolar cytomorphology with two thin, often wavy processes (Fig. 1). These cells were found frequently in the lamina propria and rarely along neurovascular septa and in between smooth muscle bundles (Figs 1 and 2). These cells do not form three-dimensional networks as confirmed by confocal microscopy. Using doublelabelling immunofluorescence, the spindle-shaped cells did not stain with the control markers analysed (Table 1 and Fig. 2). The amount of c-kit-positive spindle-shaped cells increased continuously from the proximal VD to the ampulla of the VD (Fig. 3) in accordance with the density of S100 positive neurons and the thickening of the smooth muscle layer. The cell frequency of IC was significantly different in the segments analysed. A significant $(P<0.001)$ increase in cell frequency was observed from the proximal VD $(4.00 \pm 0.54$ cells/high power field (hpf)) towards the ampulla ( $11.50 \pm 4.04$ cells/hpf).

The second source of c-kit receptor-expressing cells was found in individual and vertically orientated cells within the epithelium. These cells have an oval nucleus, originated from the basal lamina and usually reach the lumen. The interepithelial cells (IEC) occurred more frequently in the proximal segment and only sporadically in the intermediate segment of the VD (Fig. 1). The ampulla showed a diffuse epithelial staining (Fig. 4). Using double-labelling IF, these IEC could not be attributed to the control markers analysed (Table 1).

The third source of c-kit-positive cells was identified as mast cells (MC), which showed the exclusive coexpression of both CD117 and MC tryptase/chymase.
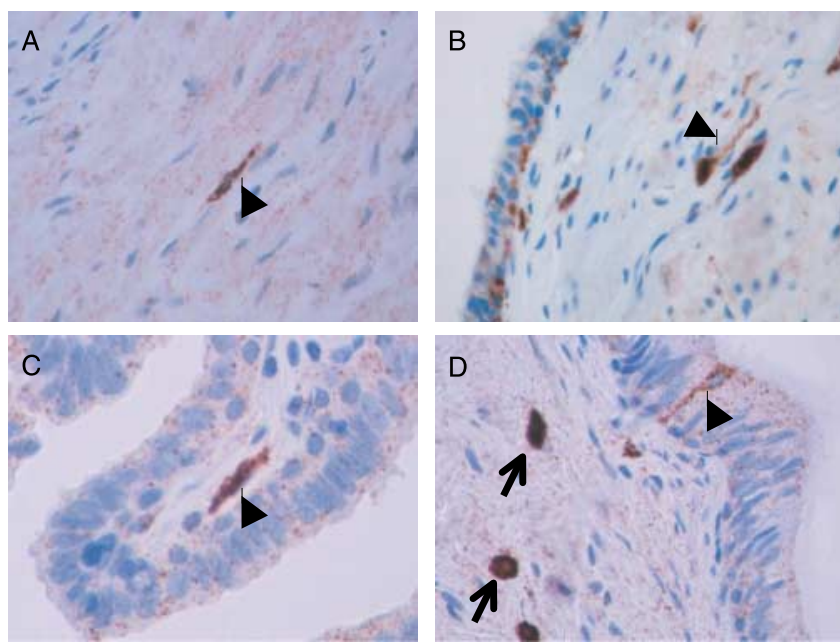

Figure 1 Expression of the c-kit receptor in the vas deferens. C-kit receptor-positive interstitial cells (arrow head) between smooth muscle cells of the lamina muscularis (A) and in the lamina propria (B and C). Round-shaped, c-kit receptor-positive mast cells (arrows) in the neighbourhood of a c-kit receptor-positive interepithelial cell (arrow head) (D). The c-kit receptor-positive interepithelial cells attach the basal lamina and reach the luminal surface. (A-D) Anti-c-kit. Original magnification $\mathrm{A}, \mathrm{B}$ and $\mathrm{D} \times 40, \mathrm{C} \times 63, \mathrm{CSA}$.
The cytomorphology of $\mathrm{MC}$ demonstrates a wide range of polymorphisms. Most MC possessed either a roundshaped cytoplasm or plump cytoplasmatic processes. Double-labelling analysis revealed that the cytoplasm of individual cells marked by anti-MC tryptase was sometimes smaller than marked by anti-c-kit (Fig. 3). MC were found in a varying amount throughout the entire wall of the VD, but usually not in the epithelium (Fig. 2). The amount of c-kit-positive MC was highest in the ampulla of the VD, followed by the proximal VD and intermediate segment, which were not different from each other (Fig. 5). A significant $(P<0.001)$ higher cell frequency was observed in the ampulla of the VD $(54.50 \pm 13.44$ cells/hpf) compared with the proximal VD $(22.50 \pm 13.92$ cells/ hpf). However, no statistically significant difference was seen between the proximal and intermediate VD.

Coexpression studies clearly revealed that c-kit-positive IC are distinct from neural, muscular, endothelial and histiocytic structures. The CD117-positive round-shaped cells were uncovered as MC. However, the interepithelial CD117 positive cells could not be attributed to any other marker used.

\section{Discussion}

The present study demonstrates the complex morphology and distribution of the c-kit receptor (CD117) in particular cells of all layers and segments of the human VD, confirmed by the uniform reactivity of various anti-c-kit receptor antibodies. Whereas the majority of these cells were identified as intermingled MC, we found two distinct c-kit-positive cell types, negative for all other analysed cell markers. These cells occurred either in the epithelium (IEC) or in the lamina propria as well as between the muscles layers (IC). Our findings in humans are supported by previously reported ultrastructural evidence for ICC-like IC in the monkey VD and immunohistochemical studies in the guinea pig (Leong \& Singh 1990, Burton et al. 2000). These cells were also more densely distributed in the lamina propria than in the muscle layers.

The existence of CLC in the upper and lower urinary tract has been clearly shown before (Hashitani 2006, McHale et al. 2006, Lang et al. 2007). The present study revealed numerous IC that did not form a clear network. Since CLC in VD have a spindle shape but not 'stag-horn' appearance, these cells may be more likely resemble to intermuscular ICC in the gut, which play an important role in the neuromuscular transmission and the propagation of electrical signals (Huizinga et al. 1995, Liu et al. 2003, Ward \& Sanders 2006). Alternatively, IC may act as a mechanosensor since spontaneous contractions in VD are initiated by stretching or perfusion. This specific function has been assumed for ICC within the gastrointestinal tract. Previously uncharacterized nonneural stretch reflex has been demonstrated in gastric muscles, which provides physiological evidence for a 

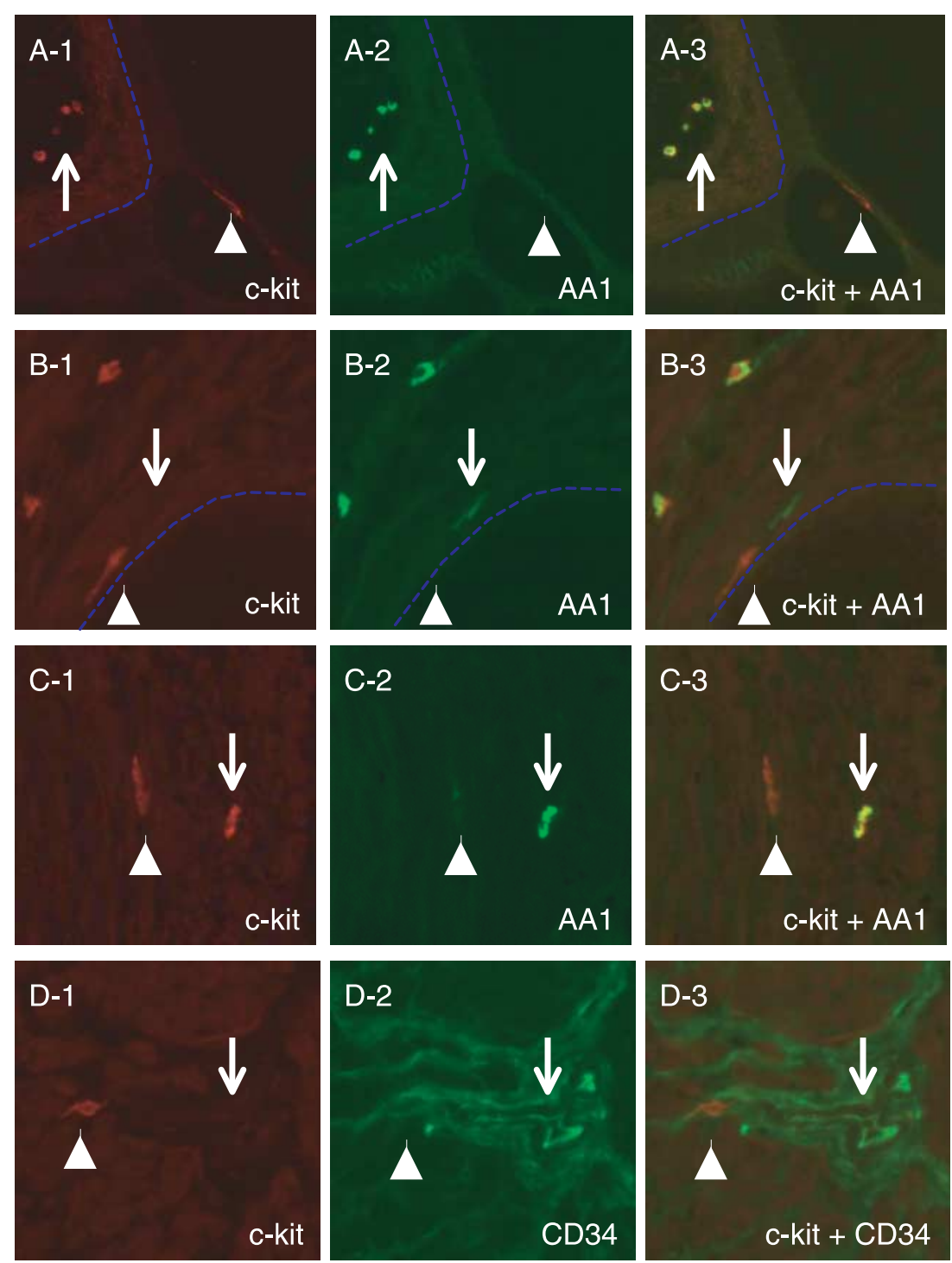

Figure 2 Double-labelling immunofluorescence of c-kit receptor and controls in the vas deferens. C-kit receptor-positive cells occur in the epithelium (A), the lamina propria (B) and the muscularis propria (C and D). (A) C-kit receptor expression in interepithelial cells (arrow head) and in mast cells (arrow) of the lamina propria (A-1), which usually express both c-kit receptor and mast cell tryptase (A-2 and A-3). The blue line marks the position of the basal lamina of the epithelium. (B) C-kit receptor in a subepithelial spindle cell (arrow head) and a mast cell (B-1 and B-3). The blue line marks the position of the basal lamina of the epithelium. Some tryptase positive mast cells (arrow) do not express the c-kit receptor and demonstrate an elongated cytoplasm (B-2 and B-3). (C) C-kit receptor-positive spindle-shaped cell (arrow head) and mast cell (arrow) within the lamina muscularis. These spindle cells are negative for mast cell tryptase (C-2 and C-3). (D) C-kit receptor-positive spindle-shaped cell (arrow head) close to a neurovascular bundle (D-1 and D-3). The c-kit receptor-positive cells do not express CD34. The arrow marks CD34 positive endothelial cells (D-2 and D-3). A-1, B-1, C-1, D-1; anti-c-kit, Cy3 (red fluorescence). A-2, B-2 and C-2; anti-mast cell tryptase mAb AA1, Cy2 (green fluorescence). D-2; anti-CD34 mAb QBEnd/10, Cy2 (green fluorescence). A-3, B-3, C-3 and D-3; red and green fluorescence. Axiovert 200, original magnification A $\times 20, B, C$ and $D \times 40$. mechanosensitive role of ICC in smooth muscle tissues (Won et al. 2005).

Modified smooth muscle cells may be capable of generating spontaneous electrical activity, which has been proven within the upper urinary tract (Brading \& McCloskey 2005, Brading 2006). Ureteral peristaltic activity begins with the origin of electrical activity at pacemaker sites. These sites are located in the proximal portion of the urinary collecting system. The 'atypical' smooth muscle cells at these sites fire 'pacemaker' potentials at a frequency higher than the 'driven' action potentials recorded from typical smooth muscle cells. In contrast to typical smooth muscle cells, these atypical pacemaker cells have $<40 \%$ of their cellular area occupied by contractile filaments and demonstrate a sparse immunoreactivity for $\boldsymbol{\alpha}$-smooth muscle actin. Expression of c-kit, a tyrosine kinase receptor, correlates with the onset of organized ureteral peristalsis in the embryo (Weiss et al. 2006). VD smooth muscle cells generate spontaneous action potential and associated contractions in the guinea pig-cultured cell models (McLean et al. 1979). It remains unclear if these cells are variations of specialized ICC belonging to the autonomous neuromuscular system of the VD. However, these cells show a close resemblance to the recently described CLC of the ureter (Metzger et al. 2004, 2005).

The ubiquitous distribution of $M C$ in the musculature and within the lamina propria of the human VD may hint to further functional properties. There is clear evidence that $\mathrm{MC}$ may also contribute to smooth muscle activity and neural stimulation by releasing a variety of substances (Keith et al. 1995, Corvera et al. 1999, Hollenberg \& Bunnett 1999, Reed et al. 2003, Vodenicharov et al. 2005). Histamines, prostaglandins and leukotrienes are potential paracrine signals in the communication pathways between $\mathrm{MC}$ and intrinsic 
Table 1 Control antibodies.

\begin{tabular}{|c|c|c|c|}
\hline Clone & Immunogen & $\begin{array}{c}\text { Concentration } \\
(\mu \mathrm{g} / \mathrm{ml})\end{array}$ & Source \\
\hline QBEnd/10 $10^{\mathrm{a}}$ & CD34 & 2.0 & Dianova \\
\hline $\mathrm{IC} / 70 \mathrm{~A}^{\mathrm{a}}$ & CD31 & 2.3 & Dako \\
\hline$S-100^{a}$ & Cow S-100 & 0.2 & Dako \\
\hline $\mathrm{BBS} / \mathrm{NC} / \mathrm{VI}-\mathrm{H} 14^{\mathrm{a}}$ & NSE & 4.3 & Dako \\
\hline $2 \mathrm{~F} 11$ & Neurofilament & 5.4 & Dako \\
\hline $\mathrm{AA} 1^{\mathrm{a}}$ & Mast cell tryptase & 2.0 & Dako \\
\hline $\mathrm{CC} 1^{\mathrm{a}}$ & Mast cell chymase & 1.0 & $\begin{array}{l}\text { Serotec, } \\
\text { Düsseldorf, } \\
\text { Germany }\end{array}$ \\
\hline $\mathrm{HHF} 35^{\mathrm{a}}$ & $\alpha$ - and $\beta$-actin & 0.6 & Dako \\
\hline $1 \mathrm{~A} 4^{\mathrm{a}}$ & $\alpha$-actin & 0.6 & Dako \\
\hline $\mathrm{KP} 1^{\mathrm{a}}$ & CD68 & 7.6 & Dako \\
\hline$P G-M 1^{a}$ & CD68 & 7.2 & Dako \\
\hline MR12/53 $3^{b, c}$ & Rabbit Ig & 1.0 & Dako \\
\hline
\end{tabular}

${ }^{a}$ Reactive on microwave-pretreated formalin-fixed tissue section.

b Used as negative control in APAAP technique.

${ }^{\mathrm{C}}$ Used as secondary antibody for antibodies raised in rabbits.

neurons or smooth muscle cells of the VD. Structural and functional relationships between i.m. ICC and MC have been documented within the gastrointestinal tract (Zarate et al. 2006). Ultrastructural analysis showed that i.m. ICC are frequently surrounded by MC with established membrane-to-membrane contacts. Furthermore, the release of cytoplasmatic vesicles directed to ICC was observed (Zarate et al. 2006). The cytoplasmatic vesicles in $\mathrm{MC}$ exhibited characteristic morphological changes defined as piecemeal degranulation that is thought to be associated with vesicle-mediated long-lasting release of the vesicle content (Dvorak et al. 1994). MC can synthesize different cytokines with proinflammatory and anti-inflammatory properties, modulating the function, survival and proliferation of other cells. Some of these mediators, such as histamine, heparin, tryptase, tumour necrosis factor and transforming growth factor, can induce proliferation and migration of fibroblasts (Metcalfe et al. 1997). Human MC represent a major source of fibroblast growth factor and in turn fibroblasts are a major source of stem cell factor (SCF), the most important cytokine-regulating growth and function of MC and ICC (Huizinga et al. 1995, Linenberger et al. 1995). Moreover, MC themselves are able to synthesize, contain and release SCF (Zhang et al. 1998, de Paulis et al. 1999). Recent studies indicate that membranebound SCF stimulates activation of the c-kit receptor more effectively than soluble SCF (Linenberger et al. 1995, Welker et al. 1999, Rich et al. 2003).

The seminal ducts serve several functions, especially, the transport of sperms from the testis to the urethra, sperm storage and post-testicular sperm maturation. Prior to ejaculation, semen undergoes a pulsatile transport from the storage in the epididymis through the VD to the prostatic urethra, called emission. So far, both processes are generally considered to function via sympathetic stimulation with supplementary parasympathetic involvement (Kolbeck \& Steers 1992, 1993). Blockage of the neural input leads to the elimination of peristaltic contractions but leaves slow rhythmic waves, indicating an independent intrinsic mechanism, which coordinates contraction in the absence of neural input. They appear, for example, when the denuded VD is stretched (Bruschini et al. 1977, Kolbeck \& Steers 1992). In our study the amount of c-kit receptor-positive cells of the lamina propria and muscularis was the lowest in the proximal portion and increased towards the ampulla of the VD. This coincided with an increase of neurons and smooth muscle cells, suggesting functional differences within a complex neuronal system of the VD in addition to the sympathetic and parasympathetic input.

The c-kit receptor-positive IEC have not previously been recognized and may have been an unnoticed cell population. One can only speculate about the possible functions IEC may harbour. These cells may own some receptor function for factors released by spermatozoa. Alternatively, IEC may also act as a mechanosensor since spontaneous contractions in $\mathrm{VD}$ are initiated by stretching or perfusion (Won et al. 2005). Or, IEC simply reflect an epithelial stem cell, reflecting the regeneration of the epithelium. Based on our purely morphological findings, these conclusions are speculative and further investigations are required to conduct this discussion. However, a functional relation with the c-kit-positive urothelial cells is suggested (Burton et al. 2000, Metzger et al. 2005).

In recent years, many studies described abnormalities of the c-kit receptor expression and ICC morphology in various pathologic conditions of the intestine. The bowel of neonatal mice treated with anti-c-kit monoclonal antibodies (mAbs; clone: ACK2) displayed no regular phasic contractions, leading to an adynamic bowel syndrome despite the presence of ganglia (Maeda et al. 1992). The c-kit receptor is likely to be required for the development of a pacemaker system in the gut (Huizinga et al. 1995). Marked abnormalities in density and distribution of c-kit-positive cells occur in anorectal malformations and intestinal atresia (Kenny et al. 1998,

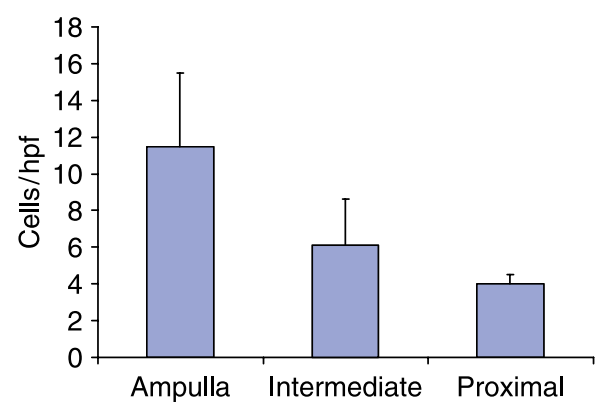

Figure 3 The figure shows the frequency (cells/hpf) of c-kit receptorpositive spindle-shaped cells in the lamina propria and muscularis propria. The cell frequency of interstitial cells was significantly different in the segments analysed. A significant $(P<0.001)$ increase in cell frequency was observed from the proximal vas deferens $(4.00 \pm 0.54$ cells/hpf $)$ towards the ampulla $(11.50 \pm 4.04 \mathrm{cells} / \mathrm{hpf})$. 

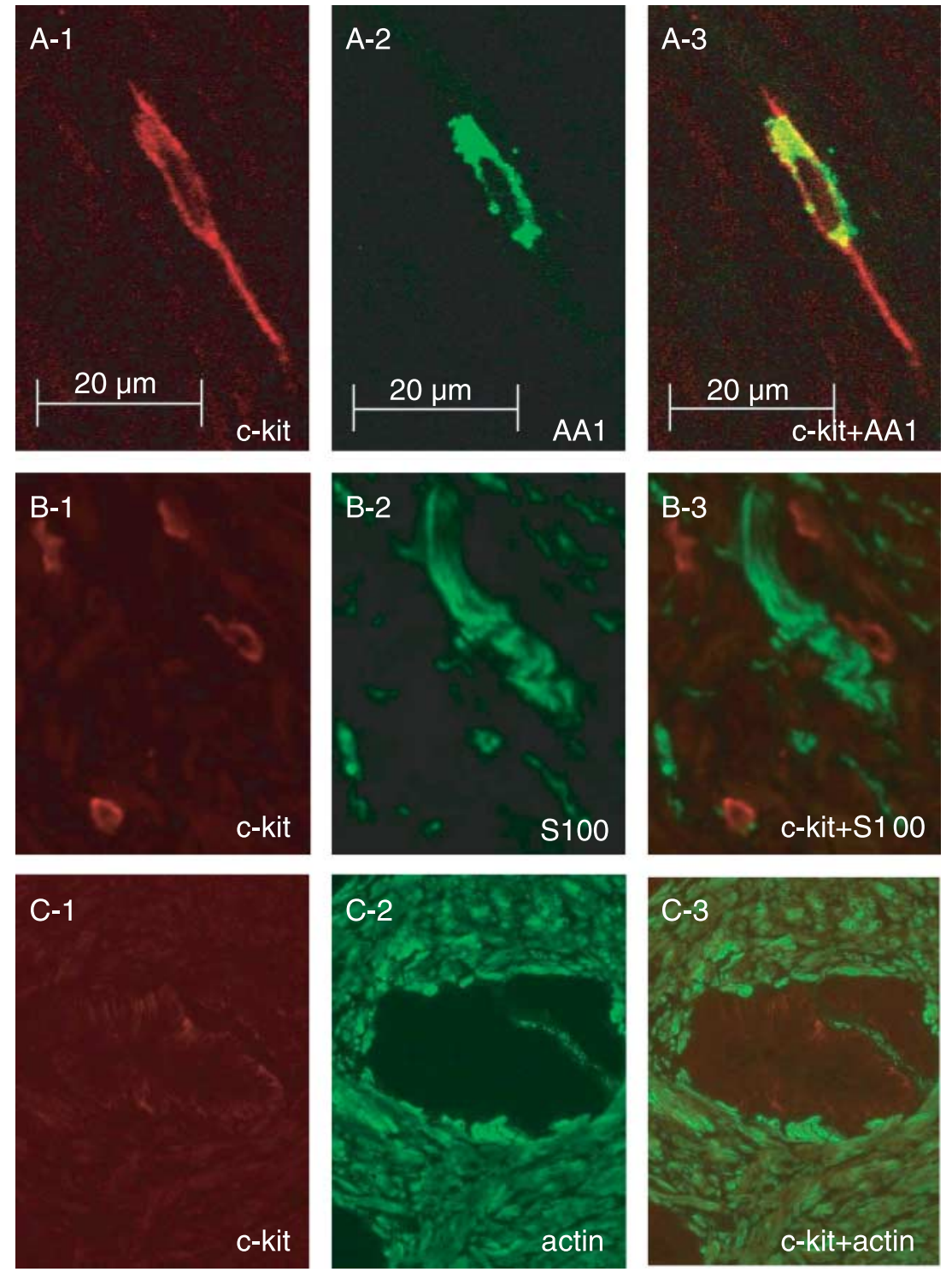

Figure 4 Double-labelling immunofluorescence of c-kit receptor and controls in mast cells and epithelial cells of the human vas deferens. Coexpression of the CD117 and mast cell tryptase in MC (A). Confocal microscopy shows that the cytoplasm marked by anti-mast cell tryptase (A-2 and A-3) in some mast cells is significantly smaller than marked by anti-c-kit receptor (A-1 and A-3). Note the perinuclear staining of anti-mast cell tryptase (A-2 and A-3) in contrast to staining of antic-kit receptor, which marks the cytoplasmatic border of long cytoplasmatic processes (A-1 and A-3). Most MC demonstrated either a round-

shaped cytoplasm or usually plump cytoplasmatic processes (B-1 and B-3). These are often located at the interface of neurovascular bundles and smooth muscle cells (B-2 and B-3). Diffuse c-kit staining in epithelial cells of the ampulla (C-1 and C-3). A-1, B-1 and C-1: anti-c-kit, Cy3 (red fluorescence). A-2: anti-mast cell tryptase mAb AA1, Cy2 (green fluorescence). B-2: anti-S100 pAb, Cy2 (green fluorescence). C-2: anti-smooth muscle actin $\mathrm{mAb}$ 1A4, Cy2 (green fluorescence). A-3, B-3 and C-3: red and green fluorescence. A: Zeiss Axioplan 2, LSM 510 Meta; B, C: Zeiss Axiovert 200, original magnification $\times 40$.
Masumoto et al. 1999a, 1999b). Inflammations have been shown to diminish the number of ICC, combined with significant ultrastructural and functional changes (Wang et al. 2002). Altered c-kit receptor expressions are reported in Hirschsprung's disease, chronic intestinal pseudo-obstruction and slow-transit constipation (Yamataka et al. 1995). Likewise, there are several disorders with a genetic or non-genetic background that affect the VD. These include malformations, obstructions and dysfunctions leading to infertility in a significant number of cases. The primary causes are often varicoceles, infections, immunologic factors and chemical insults. It is possible that alterations of the amount and distribution of IC, similar to ICC of the disturbed intestine, are involved in the pathogenesis of these disorders. Therefore, IC are good candidates for further research in a variety of important congenital and acquired diseases in male reproduction.
In conclusion, at least three differently shaped c-kit receptor-positive cells are present in the human VD. Their ubiquitous distribution within the lamina propria and muscle layers suggests a role in neuromuscular transmission and propagation of electrical signals. The importance of the IEC remains unclear. The physiological and pathophysiological significance of the cell types needs to be evaluated in detail.

\section{Materials and Methods}

\section{Patients and tissues}

VD specimens $(n=49)$ of 38 different patients were retrieved from the tissue archives of the Institute of Pathology, Justus-Liebig University Giessen. The first subset comprises tissues of 35 patients who underwent prostate or testicular tumour removal (mean age: 44, range: 36-74). These specimens were fixed in formalin and processed into paraffin. 


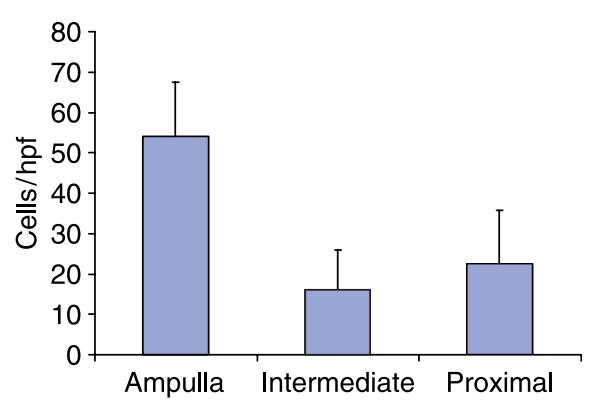

Figure 5 The figure shows the frequency (cells/hpf) of c-kit receptorpositive mast cells in the lamina propria and muscularis propria. A significant $(P<0.001)$ higher cell frequency was observed in the ampulla of the vas deferens $(54.50 \pm 13.44$ cells/hpf) when compared with the proximal vas deferens $(22.50 \pm 13.92 \mathrm{cell} / \mathrm{s} / \mathrm{hp})$. However, no statistically significant difference was seen between the proximal and intermediate vas deferens.

The second subset consisted of three autopsy cases (mean age: 48, range: 34-68) in which autopsies were performed within $24 \mathrm{~h}$ post-mortem. The causes of death included trauma and cerebral haemorrhage. Specimens were immediately placed in liquid nitrogen. Scientific use of tissues was in accordance with local standards and good clinical practise rules.

Three different segments were investigated: the proximal (pars testicularis, $n=10)$, the intermediate $(n=28)$ and the ampulla of the VD $(n=11)$. Standard tissue embedding procedures oriented the VD segments perpendicular to the longitudinal axis.

\section{Tissue processing}

\section{Frozen sections}

Frozen tissues were sectioned at $5 \mu \mathrm{m}$ by a cryostat microtome (Leica CM 1510; Leica, Wetzlar, Germany). The slides were airdried at room temperature (RT) for $12-24 \mathrm{~h}$ and then were either processed directly or stored at $-30{ }^{\circ} \mathrm{C}$.

\section{Paraffin sections}

Formalin-fixed, paraffin-embedded tissues were sectioned at 2-4 $\mu \mathrm{m}$ (Leica SM $2000 \mathrm{R}$ ) followed by drying at $37^{\circ} \mathrm{C}$ in an incubator overnight. Before immunohistochemical staining the paraffin sections were dewaxed for $10 \mathrm{~min}$ in xylene, followed by $10 \mathrm{~min}$ in acetone and $10 \mathrm{~min}$ in acetone/ Tris-buffered saline (TBS; 1:1). After this treatment the slides were washed in TBS.

\section{Antigen demasking}

If heat antigen retrieval was required, dewaxed paraffin sections were placed in microwave-proof tubes containing target retrieval solution (Dako). The slides were boiled in the tubes for $5 \mathrm{~min}$ at $600 \mathrm{~W}$ in a microwave (Bosch SS 566H; Bosch, Munich, Germany). Evaporated volume was replaced by distilled water and the procedure was repeated two times. After microwave treatment the slides were left to cool down and washed in TBS. Frozen sections were fixed in acetone for 10 min at RT and air-dried afterwards.

\section{Immunohistochemistry}

The alkaline phosphatase-anti-alkaline phosphatase technique and catalysed signal amplification methodology (Dako) were applied. The c-kit receptor (CD117) expression in tissues was analysed by seven well-characterized $\mathrm{mAb}$ and six $\mathrm{pAb}$ (Table 2; Metzger et al. 2004, 2005). Human bowl specimens were used as positive controls for anti-CD117. To differentiate c-kit-positive cells from $M C$, which are also known to express the c-kit receptor, the immunostaining was compared with MC markers (clones: AA1 and CC1). To determine the number of MC, Giemsa staining and immunohistochemistry (tryptase, chymase and c-kit) were applied. Furthermore, c-kit immunoreactivities were compared with those of different standard endothelial and stem cell markers (CD31, clone: JC/70A; CD34, clone: QBEnd/10), with actin (clones: HHF35, 1A4) as well as histiocytic (clones: KP1 and PG-M1) and neuronspecific (clones: S-100 and BBS/NC/VI-H14) markers. A nonsense $\mathrm{mAb}$ (clone: MR 12/53) served as negative control by omitting the primary antibody. The final concentrations are given in Table 1. To confirm the results of immunostaining in double label experiments, a conventional immunofluorescence (Zeiss Axiovert 200; Zeiss, Jena, Germany) and confocal microscopy (Zeiss Axioplan 2, LSM 510 Meta) were performed on paraffin sections using an Indocarbocyanin-2 (Cy2)/

Table 2 Antibodies to c-kit (CD117).

\begin{tabular}{|c|c|c|c|}
\hline Clone & Immunogen & Concentration $(\mu \mathrm{g} / \mathrm{ml})$ & Source \\
\hline $104 D 2$ & Human c-kit/membranous & 2.55 & Dako, Hamburg, Germany \\
\hline$K 44.2$ & Human c-kit/extracellular & 4.0 & Kamiya Biomedical Company, Seattle, WA, USA \\
\hline$K 45$ & Human c-kit/extracellular & 5.0 & Dianova, Hamburg, Germany \\
\hline$K 69$ & Human c-kit/extracellular & 4.0 & Dianova \\
\hline $2 E 4^{\mathrm{a}}$ & Human c-kit/cytoplasmatic & 6.8 & Zytomed, Berlin, Germany \\
\hline$T 595^{\mathrm{a}}$ & Human c-kit/extracellular & 0.75 & Novocastra, Newcastle, UK \\
\hline$Y 145^{\mathrm{a}}$ & Human c-kit/cytoplasmatic & $1: 50$ & Abcam, Cambridge, UK \\
\hline Polyclonal ${ }^{\mathrm{a}}$ & Human c-kit/cytoplasmatic & 4.0 & Dako \\
\hline Polyclonal ${ }^{\mathrm{a}}$ & Human c-kit/cytoplasmatic & 4.0 & Oncogene, Cambridge, MA, USA \\
\hline Polyclonal & Human c-kit/cytoplasmatic & 10.0 & Zymed, San Francisco, CA, USA \\
\hline Polyclonal $^{\mathrm{a}}$ & Human c-kit/cytoplasmatic & $1: 50$ & Acris, Hiddenhausen, Germany \\
\hline Polyclonal ${ }^{\mathrm{a}}$ & Human c-kit/cytoplasmatic & 4.0 & Dianova \\
\hline Polyclonal $^{\mathrm{a}}$ & Human c-kit/cytoplasmatic & 1.0 & NeoMarkers, Fremont, CA, USA \\
\hline
\end{tabular}

${ }^{a}$ Reactive on microwave-pretreated formalin-fixed human tissue section. 
Indocarbocyanin-3 (Cy3)-based method according to the manufacturer's instructions (Dianova). To suppress the strong autofluorescence of formalin-fixed and paraffin-embedded tissues, the sections were stained with Sudan Black B after immunolabelling (Romijn et al. 1999).

\section{Semi-quantitative evaluation and statistics}

The number of c-kit-positive cells was evaluated by counting immunostained cells per high-power field $(20 \times)$. For each slide three high-power fields were counted and cell density was assessed as cells per high-power field (cells/hpf). We used SPSS for Windows (Version 11.5; SPSS Inc., Chicago, IL, USA) for statistical analysis. Mean value and S.D. were assessed, and statistical analysis was performed using student's $t$-test for unpaired values. $P$ values $<0.05$ were considered statistically significant.

\section{Acknowledgements}

We thank Mrs Gabriele Scholz and Mrs Jutta Baumann for the expert technical support and the fluorescence microscopy core unit of the Institute for Clinical Sciences (IZKF) University of Leipzig for technical assistance. The authors declare that there is no conflict of interest that would prejudice the impartiality of this scientific work.

\section{References}

Brading AF 2006 Spontaneous activity of lower urinary tract smooth muscles: correlation between ion channels and tissue function. Journal of Physiology 570 13-22.

Brading AF \& McCloskey KD 2005 Mechanisms of disease: specialized interstitial cells of the urinary tract - an assessment of current knowledge. Nature Clinical Practice. Urology 2 546-554.

Bruschini U, Schmidt RA \& Tanagho EA 1977 Studies on the neurophysiology of the vas deferens. Investigative Urology 15 112-116.

Burton LD, Housley GD, Salih SG, Järlebark L, Christie DL \& Greenwood D 2000 P2X2 receptor expression by interstitial cells of Cajal in the vas deferens implicated in semen emission. Autonomic Neuroscience $\mathbf{8 4}$ 147-161.

Corvera CU, Déry O, McConalogue K, Gamp P, Thoma M, Al-Ani B, Caughey GH, Hollenburg MD \& Bunnett NW 1999 Thrombin and mast cell tryptase regulate guinea-pig myenteric neurons through proteinaseactivated receptors-1 and -2. Journal of Physiology 517 741-756.

Dvorak AM, Tepper RI, Weller PF, Morgan ES, Estrella P, Monaghan-Earley RA \& Galli SJ 1994 Piecemeal degranulation of mast cells in the inflammatory eyelid lesions of interleukin-4 transgenic mice. Evidence of mast cell histamine release in vivo by diamine oxidase-gold enzyme-affinity ultrastructural cytochemistry. Blood 83 3600-3612.

Hashitani H 2006 Interaction between interstitial cells and smooth muscles in the lower urinary tract and penis. Journal of Physiology 576 707-714.

Hollenberg MD \& Bunnett NW 1999 Thrombin and mast cell tryptase regulate guinea-pig myenteric neurons through proteinase-activated receptors-1 and -2. Journal of Physiology 517 741-756.

Huizinga JD, Thuneberg L, Kluppel M, Malysz J, Mikkelsen HB \& Bernstein A 1995 W/kit gene required for interstitial cells of Cajal and for intestinal pacemaker activity. Nature 373 347-349.

Keith IM, Jin J \& Saban R 1995 Nerve-mast cell interaction in normal guinea pig urinary bladder. Journal of Comparative Neurology 363 28-36.

Kenny SE, Connell MG, Rintala RJ, Vaillant C, Edgar DH \& Lloyd DA 1998 Abnormal colonic interstitial cells of Cajal in children with anorectal malformations. Journal of Pediatric Surgery 33 130-132.
Kolbeck SC \& Steers WD 1992 Neural regulation of the vas deferens in the rat: an electrophysiological analysis. American Journal of Physiology $\mathbf{2 6 3}$ R331-R338.

Kolbeck SC \& Steers WD 1993 Origin of neurons supplying the vas deferens of the rat. Journal of Urology 149 918-921.

Lammie A, Drobnjak M, Gerald W, Saad A, Cote R \& Cordon-Cardo C 1994 Expression of C-kit and kit ligand proteins in normal human tissues. Journal of Histochemistry and Cytochemistry 42 1417-1425.

Lang RJ, Zoltkowski BZ, Hammer JM, Meeker WF \& Wendt I 2007 Electrical characterization of interstitial cells of Cajal-like cells and smooth muscle cells isolated from the mouse ureteropelvic junction. Journal of Urology 177 1573-1580.

Leong SK \& Singh G 1990 Innervation of the monkey vas deferens. Journal of Anatomy 171 93-104.

Linenberger ML, Jacobson FW, Bennett LG, Broudy VC, Martin FH \& Abkowitz JL 1995 Stem cell factor production by human marrow stromal fibroblasts. Experimental Hematology 23 1104-1114.

Liu S, Hu HZ, Gao N, Gao C, Wang G, Wang X, Peck OC, Kim G, Gao X, Xia Y et al. 2003 Neuroimmune interactions in guinea pig stomach and small intestine. American Journal of Physiology. Gastrointestinal and Liver Physiology 284 G154-G164.

Maeda H, Yamagata A, Nishikawa S, Yoshinaga K, Kobayashi S \& Nishi K 1992 Requirement of c-kit for development of intestinal pacemaker system. Development 116 369-375.

Masumoto K, Suita S, Nada O, Taguchi T \& Guo R 1999a Abnormalities of enteric neurons, intestinal pacemaker cells, and smooth muscle in human intestinal atresia. Journal of Pediatric Surgery 34 1463-1468.

Masumoto K, Suita S, Nada O, Taguchi T, Guo R \& Yamanouchi T $1999 b$ Alterations of the intramural nervous distributions in a chick intestinal atresia model. Pediatric Research 45 30-37.

McHale NG, Hollywood MA, Sergeant GP, Shafei M, Thornbury KT \& Ward SM 2006 Organization and function of ICC in the urinary tract. Journal of Physiology 576 689-694.

McLean MJ, Pelleg A \& Sperelakis N 1979 Electrophysiological recordings from spontaneously contracting reaggregates of cultured smooth muscle cells from guinea pig vas deferens. Journal of Cell Biology 80 539-552.

Metcalfe DD, Baram D \& Mekori YA 1997 Mast cells. Physiological Reviews 77 1033-1079.

Metzger R, Schuster T, Till H, Stehr M, Franke FE \& Dietz HG 2004 Cajallike cells in the human upper urinary tract. Journal of Urology $\mathbf{1 7 2}$ 769-772.

Metzger R, Schuster T, Till H, Franke FE \& Dietz HG 2005 Cajal-like cells in the upper urinary tract: comparatice study in various species. Pediatric Surgery International 21 169-174.

de Paulis A, Minopoli G, Arbustini E, de Crescenzo G, Dal Piaz F, Pucci P, Russo T \& Marone G 1999 Stem cell factor is localized in, released from, and cleaved by human mast cells. Journal of Immunology 163 2799-2808.

Reed DE, Barajas-Lopez C, Cottrell G, Velazquez-Rocha S, Dery O, Grady EF, Bunnett NW \& Vanner SJ 2003 Mast cell tryptase and proteinase-activated receptor 2 induce hyperexcitability of guinea-pig submucosal neurons. Journal of Physiology 547 531-542.

Rich A, Miller SM, Gibbons SJ, Malysz J, Szurszewski JH \& Farrugia G 2003 Local presentation of steel factor increases expression of c-kit immunoreactive interstitial cells of Cajal in culture. American Journal of Physiology. Gastrointestinal and Liver Physiology 284 G313-G320.

Romijn HJ, van Uum JF, Breedijk I, Emmering J, Radu I \& Pool CW 1999 Double immunolabeling of neuropeptides in the human hypothalamus as analyzed by confocal laser scanning fluorescence microscopy. Journal of Histochemistry and Cytochemistry 47 229-235.

Streutker CJ, Huizinga JD, Campbell F, Ho J \& Riddell RH 2003 Loss of CD117 (c-kit)- and CD34-positive ICC and associated CD34-positive fibroblasts defines a subpopulation of chronic intestinal pseudoobstruction. American Journal of Surgical Pathology 27 228-235.

Vodenicharov A, Leiser R, Gulubova M \& Vlaykova T 2005 Morphological and immunocytochemical investigations on mast cells in porcine ureter. Anatomia, Histologia, Embryologia 34 343-349.

Wang XY, Berezin I, Mikkelsen HB, Der T, Bercik P, Collins SM, Huizinga JD \& Huizina JD 2002 Pathology of interstitial cells of Cajal in relation to inflammation revealed by ultrastructure but not immunohistochemistry. American Journal of Pathology 160 1529-1540. 
Ward SM \& Sanders KM 2006 Involvement of intramuscular interstitial cells of Cajal in neuroeffector transmission in the gastrointestinal tract. Journal of Physiology 576 675-682.

Weiss RM, Tamarkin FJ \& Wheeler MA 2006 Pacemaker activity in the upper urinary tract. Journal of Smooth Muscle Research 42 103-115.

Welker P, Grabbe J, Gibbs B, Zuberbier T \& Henz BM 1999 Human mast cells produce and differentially express both soluble and membrane-bound stem cell factor. Scandinavian Journal of Immunology 49 495-500.

Won KJ, Sanders KM \& Ward SM 2005 Interstitial cells of Cajal mediate mechanosensitive responses in the stomach. PNAS 102 14913-14918.

Yamataka A, Kato Y, Tibboel D, Murata Y, Sueyoshi N, Fujimoto T, Nishiye H \& Miyano T 1995 A lack of intestinal pacemaker (c-kit) in aganglionic bowel of patients with Hirschsprung's disease. Journal of Pediatric Surgery 30 441-444.
Zarate N, Wang XY, Tougas G, Anvari M, Birch D, Mearin F, Malagelada JR \& Huuizinga JD 2006 Intramuscular interstitial cells of Cajal associated with mast cells survive nitrergic nerves in achalasia. Neurogastroenterology and Motility 18 556-568.

Zhang S, Anderson DF, Bradding P, Coward WR, Baddeley SM, MacLeod JD, McGill JI, Church MK, Holgate ST \& Roche WR 1998 Human mast cells express stem cell factor. Journal of Pathology 186 59-66.

Received 1 August 2007

First decision 24 September 2007

Accepted 27 November 2007 